\title{
Again Around the Maypole
}

IN THE SUMMERTIME, WHEN THE SUN TAKES THE SKY CAPTIVE TILL you forget there has ever been a winter, you can see everything from the schoolhouse windows. The whole town, nothing more than the last stop of a railroad caught between glacier and copper-filled mountain, filters through the bends in the glass. If anything could grow out here, they would put us to work for a few months and make us useful, but the ground is frozen three feet down and lessons stretch all year while the miners drain the mountain. It is recess, so I stay in the back room, flip the pages of an old biology primer, and watch the boys play shortball on the narrow diamond ploughed into the moraine. There are only eight of them, so it isn't much of a game. I watch the younger girls run around the maypole, ducking and jumping and carefully brushing dried mud off the edges of the ribbons. And I watch Lizzy Jennings sneaking out of the workmen's bunkhouse, creeping along beneath the railroad trestle that runs through town, trying to make it back to the door of the schoolhouse unseen.

Back home, we never had school during the summer months. Mother would take me (and William, once he was old enough) into town on the streetcar, and we'd explore the city shops for hours before heading back to Mission Hill. But home hasn't been home for three years now. Summer outings here are reduced to the recess hour, and 
now I am denied even that. For months last fall, my father read me news reports of Boston suffering from the Spanish fever and told me how grateful I should be that we'd come all the way out to the Alaska territory where it was safe.

Of course, the influenza reached Alaska at Christmastime, and our town not long into the new year. William and I went into the hospital on the same day. Mother says he had it first and gave it to me, but I don't remember exactly how it happened. I think she just doesn't want me to feel responsible. I do remember waking up in the hospital to the steady rhythm of hammers as men built a shed big enough to hold bodies till the frozen ground would give way in spring: a swift group burial for the residents of the limbo house. Every part of me felt untethered from the rest. I needed to find William, to let him know it would be all right. I jammed my elbows behind my back and pushed myself upright, only to find William watching me from the next bed over and smiling. He pointed to his watch, and swayed his head back and forth with each hit of the hammers, keeping time. I was in the hospital ten days before they sent me home for the rest of my recovery. William was in the hospital four days before he died.

Even if Miss Trombly would allow me out to recess now, I'm not sure why I should want to go. The boys never let me play, the maypole girls aren't old enough to know that ribbon is cheap, and Lizzy almost never talks, to me or to anyone. She didn't come to the hospital either, when her father was two beds over from mine. He was the only one of the company directors who died in the pandemic. The mill workers in the hospital with us seemed to like him. They went quiet when he died, alone like the rest of them, and one man even cried. Maybe that wasn't liking, though. Maybe that was fear.

I hear a tremendous crack, and turn to see the ball from the boys' game careen off the bunkhouse wall onto the stretch of land between it and the schoolhouse. Lizzy stops dead behind a beam of the railroad trestle. I imagine her holding her breath. Lizzy was intimidating long before she was quiet. She was tall, almost full grown. Before the boys hit the five-foot mark on the schoolhouse door, she began to develop. At first, she hunched over and hurried awkwardly from place to place so as not to risk upsetting the balance of the universe. Something changed while I was out of school, though. When I came back, she'd 
straightened and slowed her walk, hips rolling in horizontal waves, looking every passerby directly in the eyes. Seeing her hide under the trestle reminds me of the old Lizzy, and I forget to be afraid she'll get caught.

One of the boys appears from behind the schoolhouse in search of the ball. He'd been William's best friend. At least once a week he'd join us for dinner. The boys would hardly acknowledge us or their food as they engineered plans to build a raft that would carry them from the edge of the glacier through the mountains and canyons and out to the ocean. It was the most detailed and least practical scheme of all time. They were eleven. He retrieves the ball without so much as a glance toward the trestle, then disappears back behind the schoolhouse. Lizzy waits another minute for signs of retaliation from the bunkhouse, but there is nothing and she is back on the move.

Lizzy and I are the only students left our age. Boys are sent off to preparatory schools, girls to finishing. Some families leave entirely so they can stay together. That was not our plan. I was to go back to Boston, but now my father says that I'm too weak to travel. I told Miss Trombly once that I didn't think that was the case, and she nodded seriously, and said that she was sure my parents knew what was best. I was back at my desk before I realized she thought they were keeping me here out of grief. I wanted to run back up, to tell her they didn't want to stay here without William, but didn't want to go back with just me. That they didn't know what to do, so they did nothing, just like Lizzy's mother. But Miss Trombly had busied herself with one of the younger girls, and I kept it to myself.

Lizzy sneaks back to the doorway and stomps her feet on the way in. If Miss Trombly knows where she's been for the last hour, she doesn't say. She keeps her back turned from us and writes out lessons on the board for each year until the younger ones come in, and she welcomes them warmly back to class. Lizzy sits next to me and takes the book. She trails her finger along the page as she reads, and I find myself following along, staring at the certainty in her movements. Her finger starts tracing a strange pattern along the page. I try to get a closer look and I realize she's pausing over every variation of the word "Stop" and I turn back to my own work, embarrassed. 
The next day when Miss Trombly dismisses us for recess and says, "Abigail, of course you're welcome to stay," which she has said so often it doesn't sound like words so much as an empty melody, Lizzy is gone before I even notice she has moved. I stare out the window at the bunkhouse. There's an entrance on this side, two doors that open up widely to the world, but that's not the one Lizzy would go to. Around the edge of the bunkhouse closest to the train, there is a smaller door. It's only a few feet from the shadows of the trestle. I've never seen it open, but then it's awfully hard to see unless you're right up close. That must be Lizzy's door.

The hour ticks by and Miss Trombly says nothing. I keep hoping someone will open the main door, will let in enough light that I might see inside, but right now summer doesn't reach in there. There's no movement at the door this far from shift changes. We see the eight oclock shift change in the mornings before class starts and from my parents' house up on the hillside I can watch the eight oclock night shift change, but it seems so still in the middle of the day. Miss Trombly tells us never to make loud noise on that side of the schoolhouse because the night men deserve their sleep, but I've heard some of the older boys tell each other stories of sneaking out at night and hiding just below the first floor windows and looking in on the men. Bradley said they don't speak English, but whisper in all sorts of strange languages. James said some of it was English but just cursing, and that Bradley was just too chicken to repeat it. When I see them at shift change, there are too many of them, too much happening to pick out any words to understand. They move like water, swelling and surging and digging distinct channels to the mines, to the mill, to the power plant, and back to the bunkhouse twelve hours later.

I watch the main door so long I don't remember what I'm hoping to see when something moves in the corner of my eye and it's the edge of the back door opening as Lizzy slips out. She's fast to the trestle again and stops behind a wide beam, concealing herself from the boys playing ball. She darts from shadow to shadow and my heart is racing for her when she stops and looks right at me. I feel my cheeks getting red, but I manage not to look away. When she comes into the classroom, she sits next to me and takes my pencil and writes in cramped handwriting low on my paper, "When did you?" and pushes the pencil toward my hand. 
"Two days ago," I write. Lizzy nods slightly, accepting. Miss Trombly makes a show of clearing her throat, then returns to the lesson. "Does she know?" I write, glancing up at Miss Trombly. Something flashes across Lizzy's face that I don't recognize, and she doesn't answer.

Whatever is in Lizzy's head keeps her company for the next hour as the little ones work on letters and she and I write essays on Othello. I don't know what good we're getting out of it. In each possible future I have in front of me, it won't ever be necessary to explain the effect of the meter on my interpretation of the play. And if I'm ever so lucky as to be in a city where it's performed, to put on fine clothes again and see real actors on a real stage and not just the Christmas pageant in the assembly hall each year, there's a significant chance that having suffered through this essay will ruin the experience. I am cursing Miss Trombly in my head with all the words Bradley won't say when I realize that Lizzy has been tapping her pencil on the corner of my paper.

"Come with?" she's written.

It TAKES ME TWO DAYS TO RESPOND. Lizzy pays no attention to me for those days, which was exactly how she treated me before. I should be used to it, but the past nothing has transformed into an absence of something, which is somehow vastly different. Before the hospital, I would have told her no. I would have told her no and then told Miss Trombly someday when Lizzy was out of hearing and Miss Trombly would have thanked me for trusting her with such news and given me a hug and then, during class, when Lizzy made a show of ignoring me, Miss Trombly would give me a comforting smile to reassure me that I was a good person and I had done the right thing. Only since I came back, Miss Trombly's done almost anything to say nothing to me at all. On Friday, I catch Lizzy looking at me and there's something in her eyes that's not the usual indifference but almost hopeful and I whisper "yes" and turn back to the lesson.

The weekend dredges long and slow. My mother has me help her with the cooking and the wash, and we stretch out the chores to fill Saturday. The house is quiet, since my father only takes Sundays off now. Six days a week he sits at a special desk and determines how rich in copper each batch of ore is before it gets loaded onto the train. If 
it's good enough, they send it off to be smelted and sold all over the world. If it is not, it's crushed further and further until they can siphon off the few good parts and trash the rest. My father is an expert in determining value.

Even when he's here, the house is not much louder. He doesn't have the same aversion I have to reading one of our twenty books for the fourth or fifth time, and so he keeps himself busy. "They have libraries in Boston," I want to tell him, but it won't help. I watch him read sometimes, sitting on the third stair up with my feet on the first, and the emotions from the book play over his face like he's never felt them before. He doesn't know I'm watching, and it's the only way I ever see him cry.

Lizzy doesn't come to church on Sunday, but that doesn't surprise me. Sunday mornings, the assembly hall, which was a dance hall the night before, becomes the church, and the fiddler becomes the preacher, and all the management families and some of the workersmostly the Italians-fill up the benches. Her mother sits three rows in front of us, chatting warmly with Mr. Marigold, the managing director, and his wife. She is kind, but this is business. My mother asked my father the other day over dinner how long the company would still be hosting Mrs. Harold Jennings after the passing of Mr. Harold Jennings. He shook his head, he didn't want to talk about it, which I think is how the company's reacted too, seeing as it's been four months and they're still here and Mrs. Jennings is charming upper management before the service. Mrs. Bromsky starts playing the upright piano and the preacher walks up onto the stage, and everything starts to die down. Everyone always looks disappointed when the service starts, even though that's what they came here for.

At dinner that night, when it should be dark but isn't, my father almost makes it through the whole meal before he starts to pull away.

"It was delicious, Dot."

“There's plenty more, if you'd like it." My mother doesn't mention the plenty more that's already on his plate. We can fit some of it in the icebox, next to the remainder of last night's dinner he didn't eat, and from the night before that, but most of it will go to waste. She knows 
this, but she keeps cooking for four when there's barely three eating, so I don't know what she expects.

"I'm quite full, thank you." He disappears into his study.

I WANT to PAY attention to Miss Trombly on Monday. My eyes are forward, but my fingers can't keep steady and the pencil is shaking so much I have to put it down. Miss Trombly's words are muddled, and every time I reach out to catch one, ten more of them slip by. Lizzy kicks me under the table and I realize the classroom has cleared out. She puts her arm around mine, and leads me out the door before Miss Trombly can tell me I'm welcome to stay. We edge along the train trestle, under the flatbed cars that hold steady with every hundred-pound sack of copper the mill dropped on them. Each time a bag lands, we use the cover of sound to move farther and farther down, closing in on the back door of the bunkhouse. Lizzy stands tall under the rails, but tiny copper tailings fall through like green rain from a few feet above and each time they hit me I jump and grab tighter on the beams we're hiding behind.

There are at least five splinters in my palms before we reach the door. I'm anticipating more evasive manoeuvres to sneak in, but Lizzy just walks up to the door and opens it and I follow. I know I shouldn't, but I look back at the schoolhouse before closing the door behind me. Miss Trombly is standing at the back window, my window. She's staring right at me. I jump into the bunkhouse and slam the door shut behind me.

It is dark. There are a handful of light bulbs on in the far corner, hissing and flickering through their cages, but compared to everywhere else in town it's a December midnight. I am overwhelmed. Somehow Lizzy is already halfway over there, past rows of half-filled bunk beds, and I quietly scamper to catch up. The beds give way to tables and benches, and under the lights are four men playing cards. They see us. I'm frozen but Lizzy keeps moving, barely noticing that we've gotten their attention. When my legs start to function again, I follow her lead, affecting a confident air that doesn't sit well on me. 
"She's new," one says.

"You sure, Lizzy?" says another as she slips on to the bench next to him. He is wiry but loose, uncoiled. His muscles make ripples in his forearm as he shuffles the cards. He does not look to Lizzy for an answer.

"She's familiar," says another, and this one keeps staring. In the dark it's hard to be sure-he only ever spoke to me once the entire time he was laid up across from me and William in the hospital-but I walk closer and it's the same eyes I saw watching me. It's Henry.

Lizzy's whispering something into the dealer's ear that I can't hear.

"Would you like to sit down, Abigail?" Henry asks, making room beside him as the game starts up again. I sit there because I don't want to have to face him directly, but after a few minutes I realize I may have made a mistake. His right hand is next to my left, his side is next to mine. He was gaunt then, but now he's been rebuilt and gives off a disconcerting warmth. When he speaks, I feel it echo against my eardrums. It would be better to be looked at from across the table.

After a few hands, I can feel my hesitation slipping. The men are kind to me, when they remember I'm here, but the important thing is the game. Dominic, the one next to Lizzy, tells me we need to keep quiet to let the men in the bunks sleep. Lizzy whispers dramatically to him that I'm not an imbecile, that I understand.

She turns to me and says, "They had rooms upstairs, but everybody sleeps down here now," resting her head on Dominic's shoulder and closing her eyes.

"It was quarantine," Henry whispers in my ear, raising his gaze to the staircase. I don't respond.

Dominic gently pushes Lizzy's head back up and away from him. He tells me all about the other men at the table, warning Lizzy and me that we'd be better off with our own kind, and shouldn't mix with the likes of Norwegians and Germans. The other two men at the table make gestures at him I've never seen before, but are almost certainly rude. Dominic says they get along well enough though, now that Sylvia's taught half of them English. Lizzy laughs, then cups her hands in front of her mouth and whispers "Miss Trombly" loudly across the table. It is the first time I've ever heard someone call her by her first name. I didn't 
know what it was. Even our parents call her Miss Trombly. I assume it's supposed to be a sign of respect, but it doesn't sound like that when other adults use it.

"Sylvia's very kind," Henry says to me, but Dominic just keeps playing, and winning more often than not. Henry plays well but not as well, and when the recess hour is almost up, he's only up a dollar to Dominic's five, but the other men only have dimes and nickels.

"Lizzy," I say, "it's time."

"She speaks," Henry says kindly. "See you soon, Abigail."

It's awful to go back into the light, but the trestle isn't as frightening this time around. When we walk into the classroom, Miss Trombly says that she's glad I'm feeling better, and then doesn't speak to me the rest of the day.

LIZZY STAYS SILENT IN THE SCHOOLHOUSE, but starts talking to me on our way to the bunkhouse the next day and each day after. I am amazed at first at how much she talks, but then I think of all the things she must have stored up and I try not to interrupt her. Over the next few days, I hear everything from the past few months and most things before then. She tells me about the climbing under the tramlines up to the mines on the ridgeline. About sneaking down to the edge of the glacier after her mother had gone to bed to find the ice caves the boys talked about before class. About everything she did because she didn't know how much longer they'd let her stay here. I realize this girl beside me bears only a passing resemblance to the one I thought I knew before. William would have liked this Lizzy, if he'd had the chance to meet her. He'd have liked her more than me. After a while, she tells me everything her mother told her about how her father died. I can't tell if she knows I was there, but she doesn't ask questions and I don't offer any answers.

Henry is different. He may not bring up William directly, but he talks to me about his parents back in Ireland and his brother, and always leaves an opening. His accent gets stronger when he talks about them, like they take him so far away he forgets he's trying to assimilate. When I'm with him, memories from the hospital I'd never remembered before come back so quickly I think I'm hallucinating. But I know they're real. I haven't talked with him about William yet, 
but knowing that the chance is there gets me through the parts of the day that aren't in the bunkhouse.

The second week of this new life, Miss Trombly stops me on the way out the door. Lizzy has already gone, and through the window I can see that she's not waiting. She looks back once, but makes her way steadily beneath the trestle. Miss Trombly clears her throat, and I look away quickly.

"I'm happy to see you're feeling better, Abigail."

"Thank you."

She starts to say something, but stops herself. She looks selfconscious, which I've never seen before.

"Do you need anything?" I ask.

"If you ever feel uncomfortable somewhere, it's probably not the right place to be."

My stomach starts to twist. "I know that."

"I know you feel sorry for her, and she's had a difficult year-"

"I've had a difficult year, too."

"I didn't mean to suggest_-"

"Can I go now?"

I don't wait for her answer. Without Lizzy, I'm not brave enough to venture over there, to open the door to the nighttime inside, and I sit instead in the dirt against the schoolhouse watching the little girls run again and again around the maypole. They look so tremendously happy, and it's hard to remember ever being one of them.

I feel a tap on my shoulder just before the hour is over. It's Lizzy. She tells me Henry missed me and I pat the ground next to me. She sits, and I ask her if I missed a good game.

"They didn't play this time," she says. I look at her, questioning, and she says, "They don't always play."

I nod, though I'm not sure why. I tell her about Miss Trombly keeping me back. "She knows, I think," I say, unwilling to admit my certainty. "I don't think we can go back."

Lizzy snorts. She looks around to make sure no one's close enough to listen, and she tells me the truth about Miss Trombly. 
According to Dominic, Miss Trombly isn't twenty-two like she tells the students. She's twenty-seven, turning twenty-eight this August, and she doesn't have anywhere else to go. She moved out here from Philadelphia with no family to speak of, and she's been trying to make a family ever since. Dominic told Lizzy that shed gone after so many of the men, they didn't know who to run and find when she showed up at their door.

My head starts to ache. Lizzy leans in closer, and tells me she saw Miss Trombly at the bunkhouse once, before I was back in school. Lizzy was already inside. There was a knock at the back door, and one of the men in the bunks opened the door and there she was, looking lost. I ask Lizzy if Miss Trombly saw her too, and her eyes get dark and she says, "She saw me. She pulled me outside."

"How did you ...?" I ask.

"I told her that if she told on me, I'd tell on her," Lizzy says, smiling. She tells me Miss Trombly didn't have any more business being there than Lizzy did. Even less, maybe, since Lizzy was invited. The company wouldn't keep Miss Trombly on the payroll if they knew she was whoring around. Lizzy grins when she says this and I squeeze my eyes shut.

"If that's really what's happening, why haven't they fired her already?" I ask.

"No proof without me saying so. That would require someone willing to admit he'd been with her." Lizzy pops up, brushes the dirt off her skirt, and strides toward the classroom door.

It feels wrong to listen to someone talk about Miss Trombly like that, but I can't get it out of my head all night. Why would she do it? There are only a few other single women in town. Some are much, much older, and aren't competing for anything, but there are a few about her age: nurses who comfort the men rather than exist as the shrill voice yelling at children across the way as the men try to sleep off hours and days and months of crushing rock. And she's not beautiful. In a certain light, there is a grace to her looks, but then she turns or steps into a shadow and it disappears. I've always seen that as a simple fact, though I suppose I never considered how disappointing it must be. What it might lead to. 
When I go to school the next day, I can't see any kindness in her features, only resignation, and I know that Lizzy must be right: she's not worried about our well-being, she's worried about competition. I am sad for her. At recess, at Lizzy's suggestion, we don't sneak under the trestle this time. We walk slow and tall the thirty yards to the bunkhouse out in the open. Anyone can see us from any window as we walk in the front door.

Henry smiles as we come in and I smile back, but Dominic keeps his eyes on the cards. The others barely look at us. They've seemed wary of Lizzy for a few days now, but it's spread to me, too. Henry tries to paper over their silence with patter about his cards. No one joins in as we take our established seats.

"Back door not good enough for you anymore, girl?" Dominic asks Lizzy.

"Just didn't see the reason to," she says, leaning into him.

"Lord help us if we're ever looking to you for reason," he says, dealing out the new hand.

Lizzy laughs, but it's hollow in a way that doesn't sound familiar.

"Abigail," Henry says, "have I told you about the time my brother and I stole a horse? Beautiful little Connemara pony. Dark gray with white spots, almost like looking at the Milky Way in the night sky."

"Not yet, no," I say.

Lizzy is whispering something to Dominic, but I can’t quite make it out.

"Two, please and thank you," Henry says, trading in his cards with Dominic. "She was a gorgeous filly. We'd stare at her every time we passed Kavanagh's farm on the way to school. We made this elaborate plan to take her-"

"For Christ's sake, Lizzy, ease off!" Dominic spits out, dropping his cards. He leaves the table and heads up the stairs. Lizzy runs after him.

"I suspect that's the game," one of the other men says, and Henry nods. The men get up from the table, put their coins in their pockets, and disappear into the darkness of the bunk beds, leaving Henry and me alone under the flickering light.

"What's going on?" I ask him, glancing at the stairs. 
"I don't think I have a good answer for that," he says, and I can't read the look on his face. I don't like the quiet that follows, and I ask him about the horse.

"Ah, the lovely Milky Way?"

"You named her because of how she looked?"

"That's how most animals get their names."

“That doesn't seem fair."

"If it makes you feel better, she didn't have time to get accustomed to it. We planned the perfect crime, but we hadn't figured out exactly what came after. So we're ten miles up the road in the middle of the night, about as far as we'd ever been from home, and I got nervous. Tommy wanted to keep going and I wanted to know how much farther we were going to go, since we'd only taken four biscuits and some carrots for Milky for our grand adventure. While we were fighting, he let go of the rope we'd tied up to her bridle and Milky ran right back home to Kavanagh's, where she went by Deidre, for the record."

"Did you get in trouble?"

"No more than usual," he says, smiling. "Kavanagh liked the story too much to give us much grief."

"Why didn't Tommy come out here with you?" I ask, though I think I may already know the answer.

"He died in the war. He was a volunteer. Passed in 1916."

"And you didn't want to join?"

"Too young at first, and then after he went $\mathrm{Ma}$ and $\mathrm{Da}$ wouldn't let me."

"Do you want to go back?"

He thinks for a minute, and there's nothing in the world but him and his past when he answers. "It won't be the same place. It isn't now. But maybe someday."

"They stopped visiting after he died," I say, and I don't know where it came from.

"I saw that," he says, and his eyes look heavy. "When your heart is broken, it's easy to forget how much you care about someone else."

"I never wanted to come here," I say. Henry nods. "Do you think they'd notice if I left?" 
He pauses. "The thing about running away-"

"It's not running away if it's with someone," I interject, and regret it just as quickly.

He traces the side of my face with his rough fingers, then rests his hand on top of mine. My cheeks flush with embarrassment and something else, elusive and unstable, underneath. "I'm afraid it is," he says. "It's just easier not to notice what you've done."

I am trying not to look at him when I hear someone upstairs crying. The sound is moving closer, and then Lizzy is running down the stairs and out the door, flooding the room with light. I pull my hand out from under Henry's and chase after her.

Lizzy lurches and stumbles toward the schoolhouse, as if with each step her feet are surprised that the ground has chosen to be there. I yell after her and she speeds up, past the schoolhouse, past the maypole. I want to go faster, I need to go faster, but my legs won't let me. I am surrounded by fresh air and light and I can't breathe. I try to yell again, but my voice cracks on the second syllable and I slump against the schoolhouse door. When I open my eyes, they are all there: the shortball boys, the maypole girls, Miss Trombly. All but Lizzy. Miss Trombly tries to shoo the others away, but they don't go far. She turns to me, looking concerned, caring, and my stomach churns. She has no right to be.

"Why didn't you stop her?" I ask.

"I only came outside when I heard you calling for her. I couldn't have reached-"

"Why didn't you stop her?" This time it comes out loud enough for everyone to hear. "You were there. You knew the whole time and you didn't stop her!”

The others are murmuring but Miss Trombly keeps her eyes locked on me. I stare back, and see everything wrong with her: the mole on her neck, stray hairs of her eyebrows all akimbo. Her lips are tight and thin, and in the sunlight I can see the slightest wrinkles forming around them. She looks down, and for a moment I feel triumphant.

"You didn't stop her either, Abigail," she says quietly, then lifts her eyes to meet mine. "People make mistakes." 
"It's not my fault," I spit out, "I'm not the one--" I pause. I can still back away, I can accept my share of the blame, I think. But she's looking at me and I can't stop myself and I whisper, "William died." She frowns slightly and I feel shame rolling in waves but the words just keep coming. "I shouldn't be ... My brother died." Tears well up in my eyes and I know they are not for William and that only makes them worse. "He's gone," I say. "It's over." And then the crying becomes a petty, ugly, unstoppable force that finally silences me.

Miss Trombly shakes her head and exhales. "No, of course. No one will blame you, Abigail, and no one should. We each do the best we can." She squeezes my shoulder, tells me it would be understandable if I want to leave and be with my parents now, then turns to gather up the class and take them inside.

I wonder what she sees when she looks at me. I wonder what William sees.

FOUR DAYS LATER, AFTER EVERYONE has found out everything, I am sitting in between my parents and Henry in the schoolhouse. Last night, my mother said that weddings are normally done in the town hall, but Mrs. Jennings doesn't want anyone else to walk by accidentally and see, so they're having it in the schoolhouse. I haven't been officially punished yet for what we did, but being here has to be part of it. Henry tells my parents why he looks familiar to them, tells them how kind William was to him in the hospital, so open for such a young man. My mother says William was always like that and my father takes her hand.

The preacher interrupts, and Mrs. Jennings brings Lizzy and Dominic in from the back room in their church clothes. Lizzy looks nauseated but hopeful. After, they will take the train to Cordova, the steamship to Seattle, and another train to San Francisco, where supposedly there is a job and an apartment waiting, but no one tells Lizzy any of the details and no one tells me anything more. Dominic looks like he lost the largest bet he's ever made. Maybe he knows more than she does.

The whole thing is over in five minutes. Mrs. Jennings whisks the Mr. and Mrs. out the door and to the train platform, and we follow. Miss Trombly is already on the train. The rumours from my outburst 
met Mrs. Jennings that night and she finally confronted Lizzy, who confessed why she was getting sick so often. My parents informed me that the company fired Miss Trombly the next day. My mother hugged me and my father looked away and told me they were sorry for putting me in a class with such a rotten influence, that the company should have gotten rid of her sooner, but I don't know if they're right. Sometimes it's just easier to start over than to figure out what went wrong. The smell of coal and oil and copper from the train is overwhelming. We watch it roar to life and carry them all away.

My parents leave to confer with the preacher, and Henry and I are the only ones left. I feel sick, but he stands tall and I try to emulate him. He looks like he's been here before. When the train is long past, and we are still staring at its void, he tells me Sylvia wasn't really like that. That she didn't deserve to get fired. That she wasn't what everyone is calling her now, in the mill and the hospital and the church when it's not a church. I want to believe him. I want to believe him as much as I believed Lizzy, but now it's hard to imagine anyone telling the whole truth. I ask him if he had ever been with her, and he says no. I ask him if Dominic had ever been with her and he won't answer.

The one time Henry spoke to me in the hospital, the first time he ever spoke to me, he said, "I'm so sorry." He says the same thing to me now. 